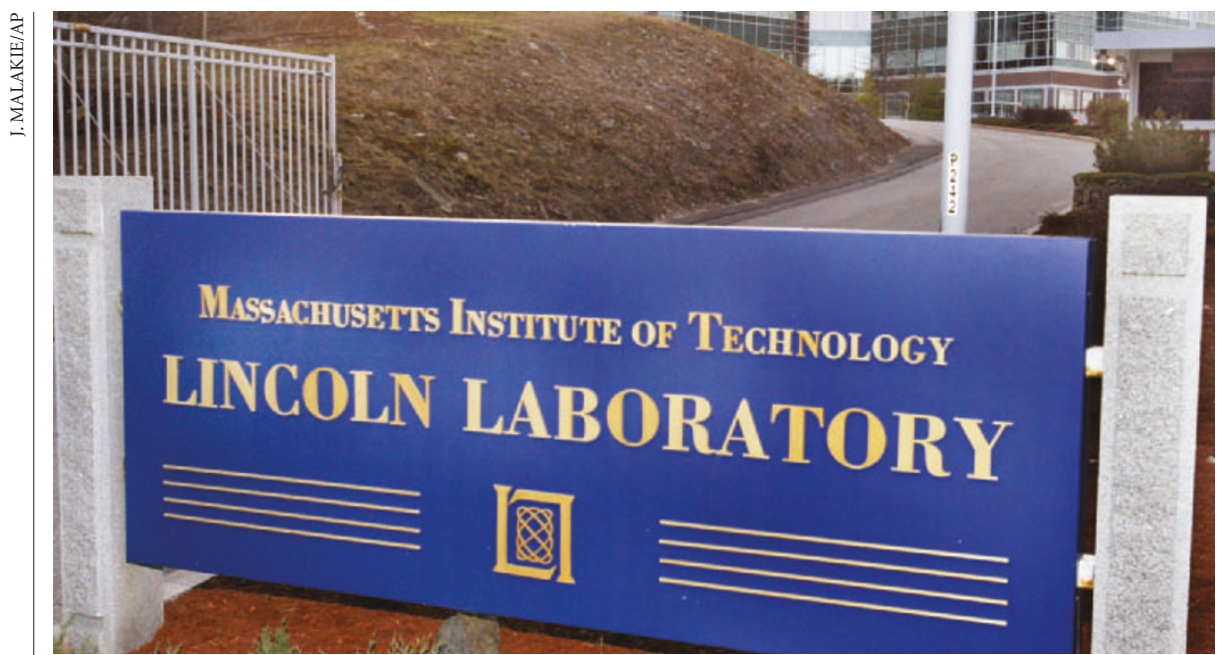

Results of missile defence tests conducted by the MIT Lincoln Laboratory will not be open to scrutiny.

\title{
Pentagon blocks MIT inquiry into missile data fraud claims
}

\section{Geoff Brumfiel, Boston}

The Massachusetts Institute of Technology (MIT) has been forced to abandon a fraud inquiry at one of its laboratories after the Pentagon denied it access to the suspect data.

The university wanted to investigate contentious missile defence tests that took place at its Lincoln Laboratory six years ago. "Without access, the investigation cannot be conducted," Charles Vest, MIT's outgoing president, said in a statement on 1 December. Vest left his position on 5 December.

Pentagon officials say that the test data are classified and cannot be released to an investigatory panel on the grounds of national security. But critics see the Department of Defense stance as a political attempt to block further inquiry into the research.

Some government watchdogs say that the Pentagon's approach threatens to undermine the integrity of academic institutions that, like MIT, conduct classified research. "It's an extraordinary situation," says Steven Aftergood, who oversees a project aimed at reducing government secrecy, at the Federation of American Scientists in Washington DC. "It should prompt a rethink of universities' policies on the subject."

At the heart of the debate is a longdisputed series of tests of a sensor designed to detect incoming missiles. Shortly after the tests were conducted in 1997 and 1998, a former engineer from the US defence contractor responsible for the sensor came forward with documents that she claimed proved the contractor had tampered with data to hide the sensor's failure.

An investigation carried out by the General Accounting Office backed the engineer, but a subsequent investigation by the Lincoln Laboratory itself, for the federal government, found that no data had been tampered with.

That led Ted Postol, an MIT physicist and established critic of missile defence, to demand that university officials investigate whether the laboratory had acted improperly. "Lincoln Laboratory knew that the sensor had failed," he contends. "And they failed to tell federal agents."

Postol wrote to Vest in 2001 asking for a separate university-led inquiry. That inquiry was launched in spring 2002 by Edward Crawley, an aerospace engineer at the university, and by the end of that year, Crawley had found enough evidence to justify a full investigation. The plan was for a review to be conducted by a select group of academics from outside MIT who had the security clearance needed to view the classified data.

But the investigation was never begun because it was opposed by the Pentagon's Missile Defense Agency. Agency officials declined to comment, but said in a statement that the agency had already been exonerated by earlier inquiries, and that a new investigation only risked leaking classified information about the missile defence system. "The extreme sensitivity of the information at issue precluded granting MIT's request," the statement says.

"The implications of this are very serious," says Sheila Widnall, another MIT aerospace engineer and former secretary of the US Air Force. Widnall chaired a panel to review the university's policy for managing classified research. For such research to be worth the trouble, the panel concluded in 2002, it must be conducted with the highest standards of integrity and in a way that is independent of the funder. "What's happening now does not meet that standard," she says.
Absence of promised bioterror committee worries researchers

Erika Check, Washington

Researchers are voicing concern that a government initiative, designed to help biologists ensure that their work isn't misused by bioterrorists, isn't getting off the ground.

Nine months after the US government said it would create a powerful committee to advise it on issues related to bioterrorism, the committee hasn't been appointed, never mind held a meeting.

It was 4 March when Tommy Thompson, then health secretary, announced the creation of the National Science Advisory Board for Biosecurity (NSABB). It was expected to advise the government on tough questions about overseeing 'dual-use' research, which could have civilian or military uses, and to write a code of conduct for scientists.

But the board hasn't appointed either members or support staff, alarming senior scientists who lauded its creation. "This is an important initiative, and it needs to move forward," says Ronald Atlas, co-director of the Center for Deterrence of Biowarfare and Bioterrorism at the University of Louisville in Kentucky and former president of the American Society for Microbiology. "Without the NSABB, the scientific community remains in limbo and guessing about what steps will be constructive as we try to prevent the misuse" of science, he adds.

Officials at the National Institutes of Health are coordinating the formation of the board. "We are close to making an announcement," says Bill Hall, a spokesman for the health department. "It's not going to be Monday, but it's not going to be six months from now."

Some biosecurity specialists worry that if the board isn't up and running soon, the government could bypass it and take extreme steps to regulate some types of dual-use biology. They also think the board is needed now to help oversee the massive biodefence research programmes set up by the United States since the terrorist attacks of 11 September 2001.

"There are so many expectations heaped on this board that they probably never would have met them," says one biosecurity specialist. "But it's hard to meet them if you don't even convene.”

For more news and analysis go to news@nature.com www.nature.com/news 